International Journal of Advanced Trends in Computer Science and Engineering

Available Online at http://www.warse.org/IJATCSE/static/pdf/file/ijatcse123932020.pdf

https://doi.org/10.30534/ijatcse/2020/123932020

\title{
SOA Implementation On Mobile Application Development : TIPBAY
}

\author{
Ahmad Nurul Fajar ${ }^{1}$, Mahfudz Amri $^{2}$, Muhammad Rakhmanto $^{3}$, Siti Royani Pasaribu $^{4}$, Salomo Pardede $^{5}$ \\ Randy Eka Pratama ${ }^{6}$, Prasetyo Jati ${ }^{7}$ \\ 1,3,4,5,6,7 Information Systems Management Department, BINUS Graduate Program-Master of Information \\ Systems Management, Bina Nusantara University Jakarta, Indonesia 11480, Email: ${ }^{1}$ afajar@ binus.edu, \\ ${ }^{3}$ m.rakhmanto@binus.ac.id, ${ }^{4}$ siti.r.pasaribu@binus.ac.id, ${ }^{5}$ salomo.p@binus.ac.id, ${ }^{6}$ Randy.e.p@binus.ac.id, \\ 7prasetyo.j@binus.ac.id \\ ${ }^{2}$ Abyor International, Serpong Kota, Tangerang Selatan, Indonesia 15322, Indonesia, \\ mahfudz.amri@gmail.com
}

\begin{abstract}
The existence of a mobile application on a variety of smartphones can be used to make it easier for parents to look for child caregivers for a short period of time. By utilizing the GPS (Global Positioning System) feature and internet connection which is generally integrated in a smartphone, parents can find caregivers children that are available with the closest location to the place of residence more quickly and easily. This application is made on the Android platform, which is one smartphone platform that is quite popular. The proposed system includes local baby sitter and parents can order available of day care agency. Also, this will provide Parents / user to local nearest baby sitter through TIPBAY Application.
\end{abstract}

Key words: Services Oriented Architecture (SOA), E-commerce, B2C, GPS finder, Web Services.

\section{INTRODUCTION}

SOA (Service Oriented Architecture) is a method to design, develop, deploy, and manage systems that represent the function of a business that can be reused [1]. SOA is currently emerging as a very popular methodology and is useful for developing the company's business and integrating enterprise applications, where SOA is a technical framework that enables companies to provide platform-independent and self-describing business function [2]. SOA examine several services with new challenges that has been explained by [3].The concept of SOA is to combine business, technology, and IT management perspectives: First, from a business perspective, SOA is used to enhance the ability of organizations to do business with their customers. Then, relate to a technological point of view, the characteristic of SOA is y modularity services that can be reused, Besides that, from an IT management perspective, SOA provides a new method for designing IT application portfolios [4].To support an application that will be built, it must use SOA technology because of an architecture that allows the process of exchanging data between parts easier [5]. SOA technology had been implemented and built in uses Location Based Service (LBS) is a service that functions to find a location by utilizing Global Positioning System (GPS) technology [6] contained in the Android mobile feature that allows it to do activities using mobile phone [7]. The use of web services is also very necessary to build an application, because the web service to combine a system consisting of data and applications to perform an integration [8], and still prioritize security by using a JSON parsing process designed to facilitate data exchange for users by providing convenience in carrying out the process. [9]. Mothers may feel they are creating a better environment for their children by choosing to stay at home, but this may create a stressful atmosphere in the home. Parents without an outlet for their stress may be hampering instead of helping their children [10]. Women who have managed to force their careers meanwhile baby sitting children at the same time report that young women do not believe they can do the same. Nannies were traditionally common to upper class or wealthy Indonesian households before 1980-ish who had busy social calendars and needed help raising their children. Today, nearly $60 \%$ of big cities families in Indonesia have nannies or caretakers in their home, and a majority of these homes do not fall into the "privileged" category. We can see in an economy and jobs, there will be the need for millions of children to be in the care of people other than their parents. Many mothers who employ nannies are actually overstretched working women, a number of whom (contrary to their professional personas) suffer from an inability to clearly express their expectations and demands to the people they pay to care for their children. The fact is 
different here. The working mothers are comparatively healthier and endure less from depression than non-working moth [11]. Based on statistics from parents and information in the nanny industry we will developed a useful Indonesian baby sitter finder application call TIPBAY, which we may like to introduce to enable working mom or parents to find their nanny and easily keep track on mobile apps

\section{RELATED WORKS}

The internet usage in Indonesia is growing rapidly, it created an ecosystem where e-commerce has a potential in opening multi sector access to new markets. E-commerce becomes vital to the business success because it can be easily accepted by the community nowadays. Electronic commerce is an emerging concept that describes the process of buying and selling or exchanging of products, services and information via computer networks including internet [12]. E-commerce offers benefits for both customers and sellers. The main benefit from the customers' point of view is significant increase and saves of time and eases access from anywhere in the globe [13]. For the sellers' point of view, it can increase revenue and reduce operation and maintenance costs through internet [14]. However, there is always a challenge in the e-commerce era such as lack of knowledge regarding the impact of emerging technologies on current architecture [15]. SOA is one of the solutions to overcome the challenge. Currently, the most widely used technologies in the implementation of application integration architecture is offered by Web Services, with some SOA concepts [16]. There is a lot of SOA implementation in e-commerce area. Implementation of SOA in E-Mall KUKM services (Ministry of Cooperatives and Small and Medium Enterprises of the Republic of Indonesia) [17]. This design can produce registration validation automation services, shopping baskets, cashiers, payment automation, tracking online shipments, and real time information by integrating Email systems, banks, shipping expeditions, and SMS gateway providers. This system is better than the previous system where the services provided only deal with promotions and information on KUKM products and transaction processes that still rely on manual systems. Implementation of the SOA method in Purchase Order Management on e-commerce systems [18]. In conventional e-commerce systems, core processes from Purchase Order Management are centralized into one application. For example, the inventory system of goods becomes one with the web portal and is not connected to other systems such as the shipping company system and the Bank's payment system. Transaction processing is long because there is no integration between systems and the absence of automation in the POM process. With the SOA design created, POM transactions can be integrated with the surrounding system and to increase customer shopping satisfaction. Transactions based on cellular phones are developing not only in the financial services sector. but also become a business sector. Users of mobile devices always experience an increase from year to year. This can make the business done through mobile devices grow rapidly. In Indonesia, m-commerce or mobile-based commercial transactions have not grown as fast as other Asian countries. But in terms of consumption, mobile users are growing faster. Mobile commerce, which is often called m-commerce in general is a mobile activity based on mobile devices, such as mobile phones. Therefore $\mathrm{m}$-commerce offers convenience, both for consumers and producers in making transactions. This is believed to be able to provide added value in the sale and purchase of goods and services. Mobile phone-based commercial transactions develop not only in the financial services sector. Will further dive in the business sector. Users of mobile devices continue to show an increase every year. Even one person can now have more than one mobile device. It is not impossible that the number of mobile devices used will be greater than the population. The results of the Accenture study of 1,100 respondents in Asia show that the Asian mobile market grows 25\% annually. Indonesia with a large population certainly has great potential. In addition, $69 \%$ of the responses chose cell phones as a means of payment. This figure is an indication of the business of the growth of mobile users. In Indonesia, m-commerce or mobile-based commercial transactions have not grown as fast as other Asian countries. But in terms of consumption, mobile users are growing faster. In addition, according to the Nielsen study, $48 \%$ of internet users in Indonesia access the internet via cell phones. This has become a potential marker for business [19]. The following are some of the examples of Implementation of Service Oriented Architecture-Based on Mobile Commerce [20].Implementation of Service Oriented Architecture In Bank Negara Indonesia. In December 2006, BNI felt challenged to implement SOA to achieve its vision. And after going through 4 phases of implementation, now BNI is able to provide an IT-based system to support its business with an efficiency increase of 50-70\%. Currently, BNI has transferred its Internet banking, mobile banking and ATM services into the SOA infrastructure. This is what makes this bank able to quickly add new features to the various electronic channels [21].Business-to-consumer (B2C) is an online transaction model with the concept of business people (goods / service owners) can market their products to consumers (customers). This concept is very good to be used by businesses to facilitate marketing of products / services [22].To boost implementation of this business model, the use of information technology is needed to improve business quality in terms of speed, accuracy and efficiency in large quantities [23], in addition to improving business quality, information technology can also build communication links between business people and customers through various online channels including online shops [23].Given that information technology services must also ensure that these services are in line with consumer expectations, especially for organizations whose business processes be determined by information technology services [23]. 


\section{RESEARCH METHODOLOGY}

Research Methodology step in assessment of SOA development for TIPBAY that we use in writing this paper represented by the diagram as below (figure 1):

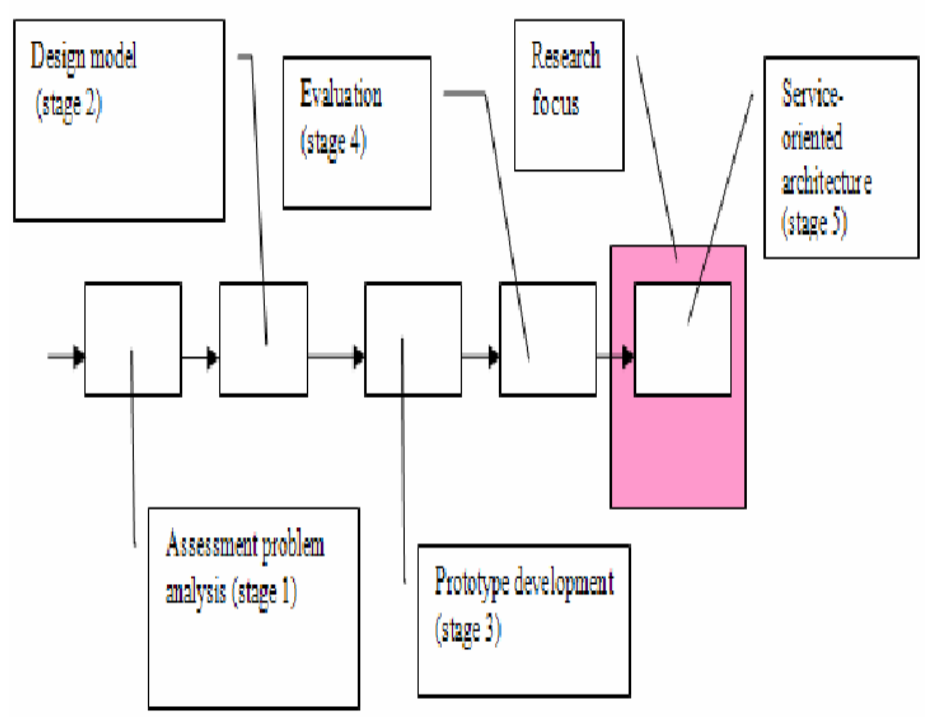

Figure 1: Research Methodology

\section{RESULTS AND DISCUSSION}

Structured Module of TIPBAY based on SOA Layer Architecture (figure 2)will be described as (1). Presentation Layer is a android mobile application that can be used as a media for users to access TIPBAY; (2). Business Process Layer explain 3 main business processes carried out by TIPBAY; (3).The service layer (front-end, back-end) of the 3 main business processes of TIPBAY above, running with several services mentioned previously which are mutually integrated through data and communication with back-end support that explains the technical links;, and (4). Integration services describe three external entities that integrated each other on TIPBAY application for essentials functions. Data and Application Layer all data used will be stored centrally on a data server consisting of data based on important components on TIPBAY

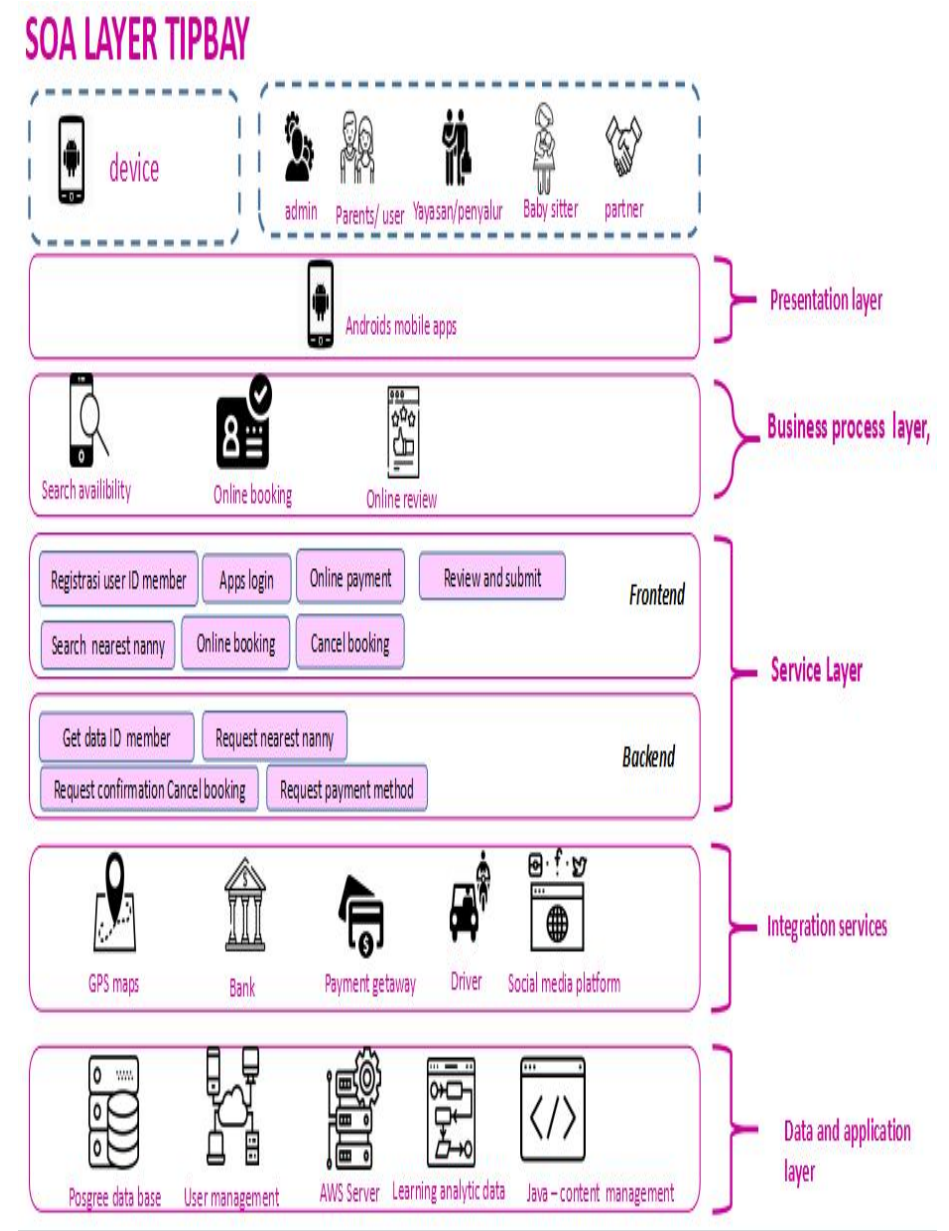

Figure 2: SOA Layer TIPBAY

TIPBAY application (figure 3)has numerous of services request and response services due to the several requirements to perform service area in the system process. All External entity which has sign the contract will give the access to the data or information which can be used by this application. Through Google Location API and load balancers those entities can communicate each other in order to exchange the data which is needed in current business process. Database is used to store all data which is used by this application. TIPBAY application is constructed using the postgresql database on the cloud server and using load balancers in order to split the traffic. When the data search process. TIPBAY application is also made using a special server and separate from the transaction process with the purpose of not troubling search process with transaction process. Throughout the data search process, TIPBAY application also using Google Location API with the purpose of finding the nearest location. 

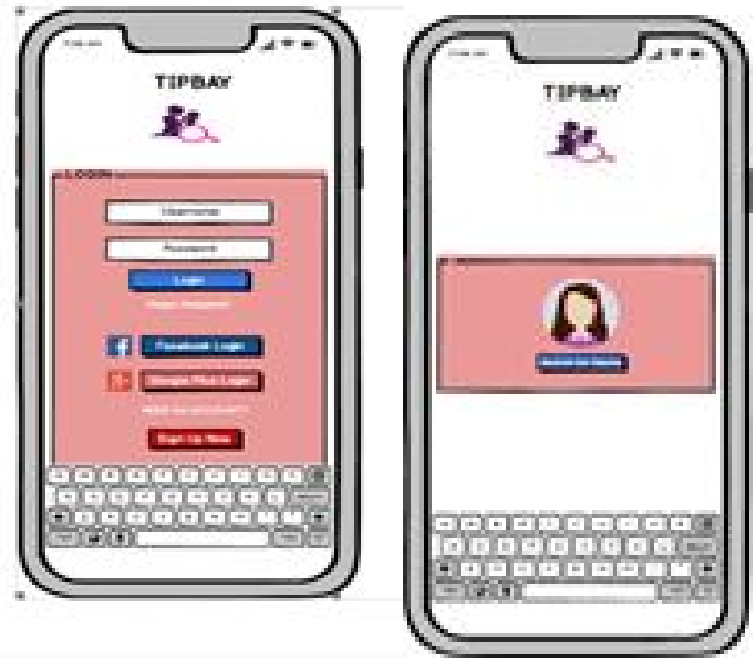

Figure 3: User interface TIPBAY application

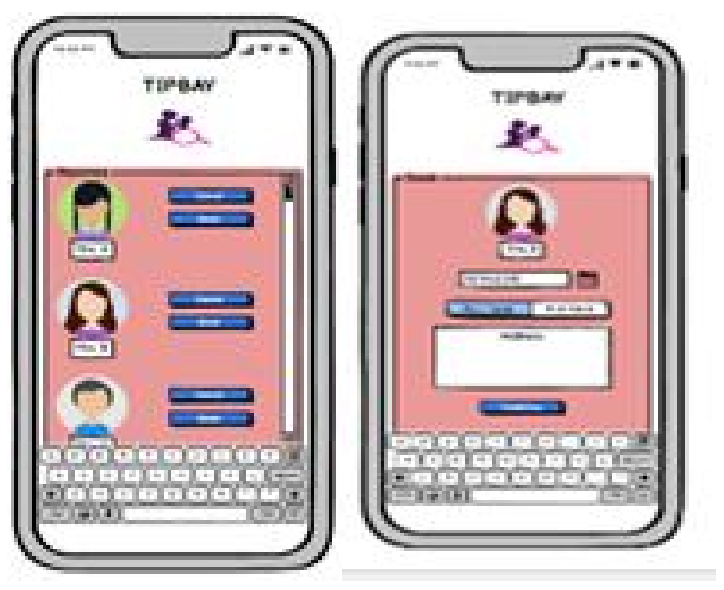

Figure 4: TIPBAY application user design

\section{CONCLUSION}

The proposed system includes local baby sitter and parents can order available of Daycare agency. Also, this will provide Parents / user to local nearest baby sitter through TIPBAY Application. Practically any software development process, including the process of software development for the Baby sitter industry, implies certain necessary features, each of which must be thoroughly worked out. The perfect type of software that finds qualified Baby sitter in the shortest terms would be an GOJEK / GRAB-like mobile app. The development of such an exemplary solution would include the following capabilities/attributes such as, Maps integration; Two account types - user \& baby sitter / agency accounts; Connection of baby sitter database; Displaying active baby sitter on the map \& hiding inactive baby sitter; Rating system with user reviews; Client notifications of baby sitter arriving at an address (for users); Connection of an Payment gateway for online transactions (for users). This study aims to produce a mobile application that can help parents to get child care facilities in a short and short period of time around them, so that they are expected to maximize activities and avoid their child being neglected.

\section{REFERENCES}

1. Malekzadeh, B. 2010. Event-Driven Architecture and SOA in collaboration, University of Gothenburg.

2. Singh, N., Tyagi, K. 2015. A Literature Review of the Reliability of Composite Web Service in ServiceOrientated Architecture, ACM SIGSOFT https://doi.org/10.1145/2693208.2693237

3. R. Hirschheim, R. Welke, and A. Schwarz, \&quot;Service - Oriented Architecture : Myths, Realities, and a Maturity Model, \&quot; MIS Quarterly Executive, vol. 9, pp. 37-48, 2010.

4. E. Hustad, C. Lange. 2014 . Service-oriented architecture projects in practice: A study of a shared document service implementation, Procedia Technology.

https://doi.org/10.1016/j.protcy.2014.10.017

5. F Kapojos, H.F. Wowor, A.M. Rumagit, A.P.R Wowor.Vol 11, No 1 (2012). Implementasi Service Oriented Architecture dengan Web Service untuk Aplikasi Informasi Akademik.

6. B. R. Rompas et al. 2012. APLIKASI LOCATION-BASED SERVICE PENCARIAN TEMPAT DI KOTA MANADO BERBASIS ANDROID.

7. Tanaem, Penidias Fiodinggo et al. 2016. RESTFul Web Service Untuk Sistem Pencatatan Transaksi Studi Kasus PT. XYZ. Salatiga.

8. Whijaya, Bakti Destian et al. 2015. IMPLEMENTASI JSON PARSING PADA APLIKASI MOBILE E-COMMERCE Studi Kasus : CV V3 Tekno Indonesia. Jakarta.

9. Jewell, Julie P. 2015. Perceptions of Mothers' Work Choices. Ohio: JMS.

10. A.S Almani et al. 2012. Study of the Effects of Working Mothers on the development of Children in Pakistan. Vol 2 No. 11. Pakistan: International Journal of Humanities and Social Science.

https://doi.org/10.5430/jms.v7n1p1

11. A.K Bairagi. 2011. Utilization of E-Commerce can Change the Auction Culture of Bangladesh Specially in Public Sector. Bangladesh: IJCIT

12. A.G. Khan. 2016. Electronic Commerce: A Study on Benefits and Challenges in an Emerging Economy. Bangladesh: Global Journals Inc

13.A.G. Khan. 2016. Electronic Commerce: A Study on Benefits and Challenges in an Emerging Economy. Bangladesh: Global Journals Inc

14.F. Aulkemeier et al. A Service-Oriented E-Commerce Reference Architecture. 2015. Journal of Theoretical and Applied.

15.S. B. de Oliveira et al. Information and Service-Oriented Architecture \& Web Services: enabling integration and organizational agility. Rio De Janeiro: 2012, Procedia 
16.Ardiyanta, Alfian. 2015. RANCANG BANGUN LAYANAN E-COMMERCE BERBASIS SERVICE ORIENTED ARCHITECTUR Volume:1, No:2.

17. Santoso, Wiro. 2014. Implementasi SOA dalam Layanan Emall KUKM Studi Kasus Kementerian Koperasi dan Usaha Kecil dan Menengah RI. Jogja: SNATI

18. Rizal, Ihsan. 2012. Perdagangan Elektronik dengan M-Commerce.

19. Wibowo, Wahyudi. 2015. IMPLEMENTATION OF SERVICE ORIENTED ARCHITECTURE ON SINGLE PAGE APPLICATION USING ANGULARJS IN TRANSPORTATION, ACCOMODATION, AND TRAVELLING ROUTE SEARCHING APPLICATION.

20. Thomas, Erl. 2005. "Service Oriented Architecture: Concepts, Technology, Design", Precentice Hall PTR.

21. WULANDARI, MUHAMAD MUSLIHUDIN, MEI LISTIARINI "PERANCANGAN APLIKASI BUSINESS BERBASIS BUSINESS TO CONSUMER (B2C) PADA WISATA KULINER KHAS LAMPUNG" Jurnal Keuangan dan Bisnis maret 2017)

22. S. Kosasi, "Design of Online Marketing Information System of Shoes for Global Market Enhancement", Techno.COM, Vol.16, No.3,pp. 278-291, 2017

https://doi.org/10.33633/tc.v16i3.1424

23. J. Wulf, T.J. Winkler, \&amp; W. Brenner, "Measuring IT service management capability: Scale development and empirical validation", Wirtschafts informatik, pp. 630-644, 2015 